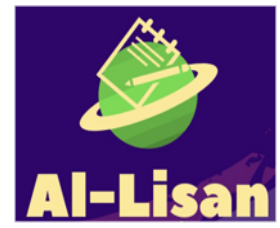

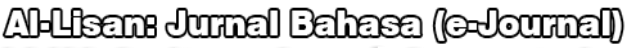
Lalli sulien Lathet colchiele Volume 5, Nomor 2, Agustus 2020 ISSN 2442-8965 (P) ISSN 2442-8973 (E)

\title{
The Analysis of Political Discourse in Anies Baswedan Interview with The Sydney Morning Herald
}

\author{
Dhion Meitreya Vidhiasi \\ mvdhion@gmail.com \\ Akademi Maritim Nusantara Cilacap, Indonesia
}

\begin{abstract}
Indeed, the political world is never free of whatever smells of controversy. News that is still widely debated is an article in the Australian newspaper, The Sydney Morning Herald, written by James Masolla dated May 7, 2020. The article was a conclusion from his interview with Anies Rasyid Baswedan, Governor of DKI Jakarta. This study aims at analyzing the political discourse contained in the video interview with James Masolla given by Governor Anies by seeing the persuasive strategy used by both people. The data obtained were then analyzed by employing the theory of persuasive strategy. Researchers used descriptive methods to tell the results of the analysis of this study. The findings of this study show that the interview with James Masolla by Anies attracted a lot of different perspectives within the audience. James' skill in supporting and directing Anies has also earned Anies supporters' respect for the Governor. The quality of the argument given by Anies is excellent because it can provide a probability claim and provide a desirably claim. This has been shown that the usage of the persuasion approach allows clarifying the meaning behind an argument. Persuasive techniques may also be utilized to forecast the reaction and the behavior the interlocutors want. There is potential for what Anies did to guide him in the contestation of the presidential election in 2024, although it is still too early to talk about it. Anies' interview, however, showed that there was a problem between DKI Jakarta's provincial Government and the national Government.
\end{abstract}

Keywords: Anies Rasyid Baswedan; James Masolla; Persuasive Strategy; Political Discourse.

\section{A. INTRODUCTION}

The latest news that is still hotly discussed is the interview of the Governor of DKI Jakarta with one of the Australian Media named The Sydney Morning Herald. James Massola, as a correspondent, later concluded the results of his interview in an article dated May 7, 2020, entitled "Not allowed to do testing": Governor says Jakarta was tracking COVID-19 cases in January ". The article then raises a variety of positive and negative responses. Especially with the number of positive cases of COVID-19 in DKI 
Jakarta as of May 12, 2020, which reached 5303 cases, making the public see the battle between the Provincial Government and the Central Government.

James Massola is south-east Asia correspondent based in Jakarta. He was previously chief political correspondent, based in Canberra. He has been a Walkley and Quills finalist on three occasions, won a Kennedy Award for outstanding foreign correspondent and is the author of The Great Cave Rescue.

Talk about politics, there is a saying that there are no eternal friends or opponents in politics. Bayram (2010:24) said that politics is a struggle for power to put specific political, economic, and social ideas into practice. Language plays a crucial role in every political action. Language is closely linked to our childhood social and cognitive development, and to the formation of our identity. A listener may take a different speaker's attitude.

Language attitudes have been described by Trudgill (1992:44) as the attitudes which people have towards different languages, dialects, accents, and speakers. Such attitudes may range from very favorable to very unfavorable. They may be manifested in subjective judgments about correctness, worth and aesthetic qualities of varieties, as well as the personal qualities for their speakers. Bayram (2010:25) explained two kinds of view toward language attitude; those are mentalist and behaviorist view. Fasold and Connor (2006:147) observed that most language research is focused on a mentalist perception of attitude as a readiness state: "an intervening variable between a stimulus affecting a person and that person's response." Bayram (2010:25) said that from a behaviorist view, attitudes could be identified clearly in the responses people provide to social circumstances. Holmes (2001:344) said that Language attitudes reflect attitudes towards users and language usages. In culture, the regular variety has a "hidden reputation".

Giles and Coupland (1991) commented on the evaluation of regular American speakers, and Kentucky accented them. The study reported Kentucky's accented speakers displayed high unity, low rank. The specific outcome showed that American standard speakers scored low on unity, great on standing. Likewise, in their study, Coupland et al. (1994) found that teachers in Wales classified Carmarthen English (characterized as the Welsh version of RP by one teacher) relatively high not only for 
reputation but also for dynamism, pleasantness and "Welshness." On the other side, RP scored strongly at prestige and, in all other respects, very low.

Such studies have shown that attitudes towards speech can define the social and cultural personality, social status, and perceptions of legitimacy and unity of others and that attitudes towards expression and its various varieties may be influenced by a variety of users' individual expression influences. This article focuses primarily on the interview with James Masolla of the Sydney Morning Herald by Jakarta Governor Anies Rasyid Baswedan, which focuses on the realization of power in the context of language use.

Skvortsova (2017) considered political discourse as a specific kind of discourse. It comprises all types of interaction of an individual and society, creating worldview. Political discourse reveals the way cultural values and social order are imposed in different societies. Political discourse is often practiced by those who have the intention of wanting to influence others. This practice is often seen when seeing a politician speak in response to an event or when they make a speech. It has been known that discourse can describe someone through language.

According to van Dijk's clarification (1997:12), their actors or writers describe political discourse, viz. Policymakers. Political discourse is about the text and professional or government bodies thinking about it. Another clarification from Amaglobeli (2017:20) is that political discourse can be defined as a deliberate act that is intended to achieve specific goals in each case and that these goals are, as a rule, real. Political discourse may be said to be used to convince, defend, or de-construct certain things. In other words, in political discourse, ideology plays an important role.

Schaffner in Bayram (2010:27) said it was possible to split political discourse into two criteria; those are practical and thematic. Political discourse plays various purposes, depending on the specific political activities. The objective is driven by one political cause or theme, such as political action, political ideas, and international relations.

An influential person can quickly be influencing others. Bayram (2010:27) described power as a complex, abstract concept that has a significant influence on human life. Power is the capacity of its holders to demand other individuals' conformity or obedience to their will. Language once again plays a vital role in making social life exchange of values and turning power into right, and compliance into an obligation. 
Rousseau in Bayram (2010:27) states that the best is only strong enough to always be monarch without altering his power to loyalty in right and obligation.

The reaction that comes from people to statements from someone can vary. Edwards (2006:324) said people do not respond to the environment based on sensory information, but rather on the sense of what we interpret the data. For example, when Ahok apologized for his case of blasphemy, many people said it was a fake apology, while some said it was a genuine apology. Hearing a particular variation is a mechanism or stimulation that evokes cognitive expectations or beliefs or stereotypes about the community that is assumed to be the speaker.

Politics is concerned with a power that is the ability to make decisions, control resources, control the actions of others, and also control their values. Politicians have achieved popularity over the centuries, according to Jones and Peccei in Bayram (2010:28), thanks to their "skillful use of rhetoric," that seeks to convince their public of the legitimacy of their views by using elegant and convincing words sensitively and deliberately. Rhetoric is the art of utilizing language to persuade or affect others; a speaker or writer will obey a set of guidelines such that it communicates it eloquently. According to van Dijk (2006:733), political circumstances involve a cognitive partnership between conditions and speech or text, that is to say, meaning. These circumstances indicate the political discourse includes not only political debate structures but also political backgrounds.

Two viewpoints, which are micro-level and macro-level, can be used to analyze the political discourse. Micro-level research can be achieved by looking at word usage, and so on, whereas from the communicative case, macro-level can be seen. Language usage, voice, verbal expression, and communication are part of the social order microlevel. The study of the macro-levels involves control, domination, and inequality between social classes. van Dijk (2003:354) explained that Critical Discourse Analysis could theoretically bridge the gap between micro and macro approaches, which is a distinction that is a sociological construct in its own right.

The Critical Discourse Analysis (CDA) was mostly linked to the ideas of Norman Fairclough, Ruth Wodak, and Teun van Dijk. Bayram (2010:31) said that CDA could be used to describe, interpret, analyze, and criticize social life reflected in the text. CDA seeks to investigate the interaction between discursive activities, texts, and occurrences 
as well as more comprehensive frameworks, connections, and procedures of social and cultural matters.

The political discourse is not just about communication. It brings its clear objectives and specific participants together. The primary purpose of political discourse is to win and deduct power, with political and social participation (Kenzhekanova, 2015). The power of an immediate manipulative impact on the minds of the public is achieved through certain political discourse representation tactics and strategies. Speech strategies are unique in this respect (Sukhanov, 2018).

Renkema and Schubert (2018:278) explain that the consistency of the argument has two aspects: the power of the argument (the predicted result probability) and the valence of the argument (this outcome's desirability). So, in arguing for or against an issue (e.g., "You should stop smoking"), one can improve the argument quality by providing a probability claim ("It is statistically proved that people who don't stop smoking run a higher risk of dying of lung cancer") or by providing a desirability claim ("If you stop smoking you will feel much healthier").

This work will give the reader exposure to the technique of self-expression (creating a politician's image). According to Titova (2018), the technique includes tactics of fair treatment with others (demonstrating that one belongs to this social and political group) as well as tactics of resistance. Two persuasive methods are presented by Kochneva and Titova (2019):

1) Arguments technique (by presenting facts to convince a recipient). This substrategy consists of the following few tactics:

a) established appraisal techniques (when a speaker tries to analyze and explain something);

b) contrast analysis tactics (confrontation and comparison of facts, events, outcome);

c) strategies of showing perspectives (predictive event growth, report on potential objectives); and

d) tactics of illustration (examples, facts).

2) Propagation strategy (the strategy of influencing people's behavior by making them do something, make a choice), which includes the tactics of promise and the tactics of appeal 
Language both shapes and is shaped by society. CDA is not so much interested in language use itself, but the linguistic character of social and cultural processes and structures. Blommaert (2019), Kochneva and Titova (2019), and Qaiwer (2020) researched political discourse. Blommaert examines language in Twitter usage, while Kochneva and Titova discuss the use of political discourse in a film. Qaiwaer examines the use of ironic utterances in political discourse.

Those researchers agreed that the way someone spoke determined the purpose behind the statement. That way of speaking is then called speech strategy. This study aims to examine how the speech strategy used by Anies Baswedan and James Masolla as a form of political discourse implementation. The researcher sees the figure of Anies Baswedan as a very influential figure. Moreover, the effects of the interviews conducted were quite noisy for Indonesians. Anies Baswedan was also predicted as a presidential candidate in the presidential election contestation in 2024.

\section{B. RESEARCH METHOD}

In this part, the author presented an analytical unit, data collection method, and data analysis. In this study, the analytical unit used is the "move," which can be a word, a phrase, a sentence, or sentences. It is stated by Webster New World College Dictionary (1997) that the word is a speech sound, or series, that communicates meaning, and consists, with or without a prefix or suffix, of at least one basic morpheme. A phrase is then a sequence of two or more words that convey or create a separate part of a sentence but which does not include a subject and predicate. It also states that a sentence is a standard unit of interdependent speech or writing that usually contains a subject and a predicate.

Sutomo (2016:24) notes that the term "jump", a written or spoken word, is the unified functional sense of a sentence or group of sentences. In this study, words/phrases/sentences are mainly segmented text discourse from the YouTube downloaded interview of Anies Baswedan. The researcher acknowledges the data verbatim and there is no alteration of the data as conclusive findings must be found in data analysis and interpretation. 
Data sources for the present study are written data as the researcher attempts to explain in an interview with Anies Baswedan the phenomena of written data in connection with the Appraisal System.

The data were collected through the following steps: (1) Browsing the website; (2) Finding the Anies Baswedan's interview with James Masolla; (3) Downloading the video of the interview from https://www.youtube.com/watch?v=IOtgmyT4FVM; (4) Transcribe the interview. The data were accessed on 12 May 2020, and they were treated verbatim.

Descriptive research methods are the approach used in this analysis. Polit and Beck (2004:192) announce that descriptive work aims at witnessing, identifying, and recording aspects of a natural situation. In describing the research, an event, condition, or situation is described in detail using quantitative, qualitative, or combined methods.

The author was using the key aspects of linguistic analysis in this study: content collection, contrast, interpretation, and explanation of the results. The author always looks at the language, taking lexical units, and conceptual sense into account.

\section{FINDINGS AND DISCUSSION}

\section{Findings}

It is no longer a secret that the interview of the Governor of DKI Jakarta, Anies Rasyid Baswedan with a contributor named James Masolla from The Sydney Morning Herald's newspaper, was a warm discussion discussed by every element of the community. Many of his supporters said that the interview was perfect because the interview showed that the Governor of DKI Jakarta was more responsive than the Minister of Health, especially the National Government. However, not a few consider that what Anies delivered in the interview was an attempt to "seek the stage" for the presidential election contest in 2024.

The interview strategies used by both Anies Baswedan and James Masolla vary. Mr. Anies often uses strategies where he wants to prove his evaluation of something. This is evidenced by providing data in the form of numbers, narrating the sequence of events, and using words that can support his statement. Anies also often used illustrations in these interviews. Mr. Anies also often provides a comparison, in this 
case, comparing the attitude of Mr. Anies as the Governor of DKI Jakarta with the attitude of the Government in handling COVID19.

One interesting thing is that both Mr. Anies and Mr. James are both using a propagation strategy, which can make someone do something unnoticed. This has been shown that the usage of the persuasion approach allows to clarify the meaning behind an argument. Persuasive techniques may also be utilized to forecast the reaction and the behavior the interlocutors want.

\section{Discussion}

The use of appraisal techniques is often used by Anies in an interview with James Masolla. This is intended to confirm something.

Anies: And then number two with the number of the real cases.

On the real cases, I'm referring to funeral services. As you know, that the funeral services in March, in the month of March and April is quite high.

Anies tried to convince James that the data provided was accurate. The use of the phrase "quite high" was said by Anies by providing a further explanation to strengthen his argument about the number of actual positive cases.

Anies: And, let me, let me check the number just a minute.

In the month of April, it is also around 4590 funerals in that month. And that is four weeks.

In the month of March, most of those service is in the third or fourth week. And the number is around $\mathbf{4 3 0 0 .}$

Grafik Pemakaman Jenazah dengan Protap Penanganan COVID-19

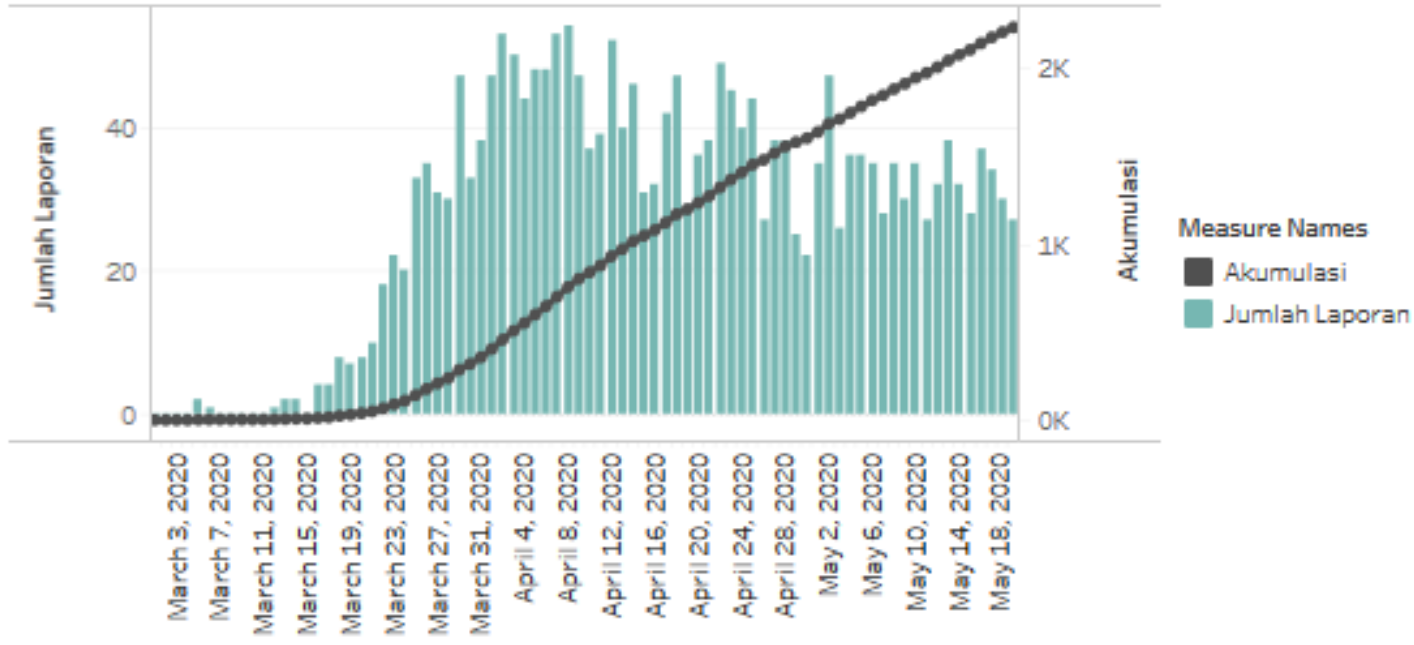

Picture 1. Funeral Chart with the permanent procedure of COVID-19 Handling (corona.jakarta.go.id) 
Something is interesting with the numbers given by Anies to James. If you look at the corona.jakarta.go.id page, the accumulation of funeral data with the COVID-19 handling procedure recorded up to 31 March 2020, touched more than 2000 figures but not up to 3000. While on 28 April 2020, 1597 bodies were buried with the COVID-19 handling protocol. Even so, the strategy Anies used in giving his argument was responded well by James.

James: Bapak Governor, what I was asking you is we ask for the information of the burial information for April, we had to go to through the national Government. Are they blocking your Government or they ask your Government not to release the April data?

The question posed by James shows that James clashed the DKI Jakarta government with the National Government. This shows that James agrees with the figures presented by Anies even though it looks different from the data showed on the corona.jakarta.go.id page. The use of tactics of contrast analysis is also used to strengthen Anies's argument further.

Anies: They are not asking us not to release, but they have been discouraging people to rely on our number.

James: Okay right.

Anies: They are saying that those are not a covid cases and it is true that we cannot say they are covid cases but average burial services is about 2700 per month and then suddenly it jumped to more than 4000 so it raised an eyebrow.

James: Yes of course, that's exactly the point of mine of course.

The use of the words "okay right" and "yes, of course" is a form of a statement that represents the proposition as highly warrantable. James's answer emphasized that what Anies said with the figures presented was indeed something that could be justified. The phrase "okay right" also confirms that there is an attempt by the national Government to influence people to distrust the figures given by Anies. So, no wonder, the pros, and cons of the data provided by Anies are even greater among the people.

The use of an argument strengthening strategy by making comparisons was also carried out by James. It can be seen from his words that praising the DKI Jakarta Provincial Government's corona page is better than the National Government's. James Masolla said: 
James: So, looking on the Jakarta website, the Jakarta corona website, which by the way so much better than the national Government's website, more information and more useful.

The choice of the phrase "so much better" can be categorized as a form of praise for something. That phrase is an assessment of the degree of intensity that operates over quality. James Masolla, as a correspondent, seems to be very good at trying to win the hearts of Governor Anies. The addition of the phrases "more information" and "more useful" shows that the COVID19 information page owned by the national Government does not provide sufficient information and usefulness when compared to pages owned by the DKI Jakarta government.

\section{Data Pantauan COVID-19 Jakarta}

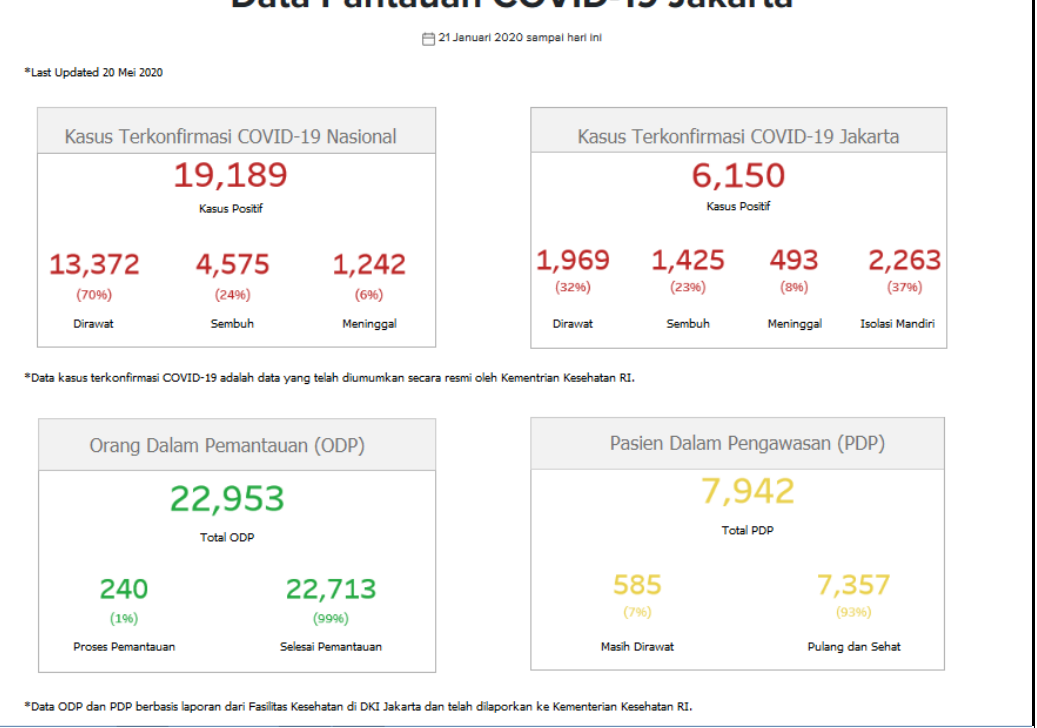

Picture 2. Data of COVID-19 from the website of DKI Jakarta (https://corona.jakarta.go.id/id/data-pemantauan) 


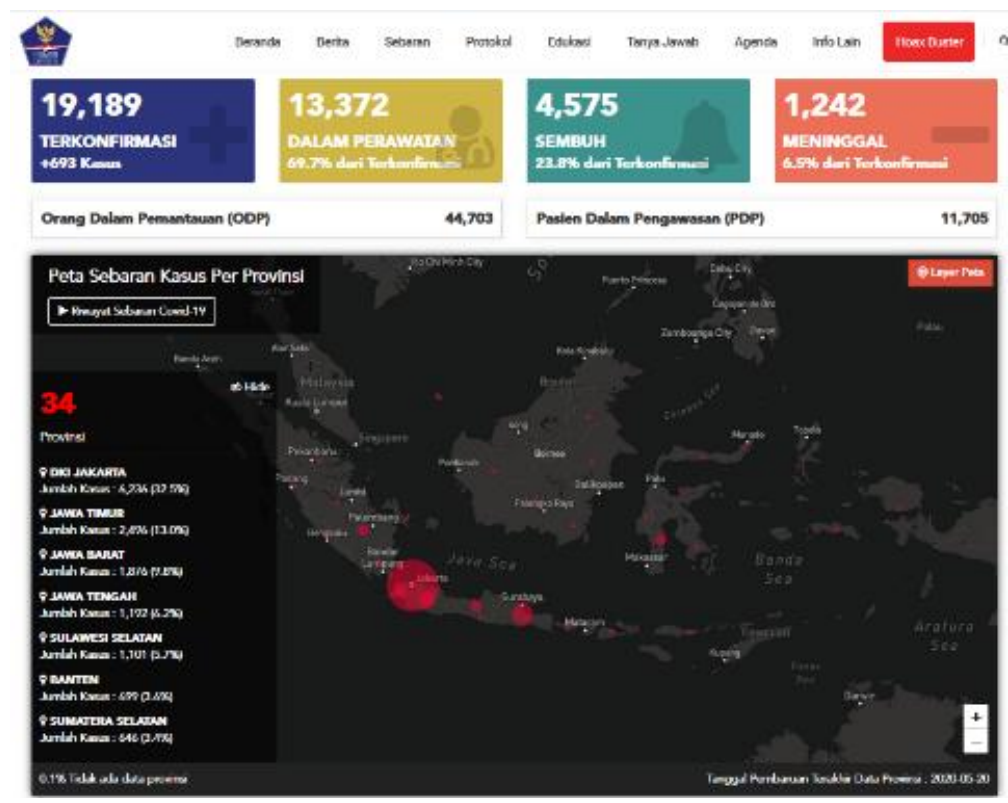

Picture 3. Data of COVID-19 from the website of National Government (https://covid19.go.id/peta-sebaran)

If we look at the comparison of the website of the DKI Jakarta Provincial Government with the website of the National Government, more or less, the information shown is the same. Picture 2 and Picture 3 are the initial screenshots for each page. From the results of the comparison, both pages provide easy-to-read information. The only difference is that the distribution map is shown on a page owned by the national Government.

The dispute between the Government of DKI Jakarta and the National Government was increasingly apparent when Anies openly shared her differing views with the Minister of Health, which was then greeted with a propagation strategy carried out by James.

Anies: And we have different paradigm on that. The ministry of health don't share that view. That's more of the tension.

From our side, being transparent and telling what to do is providing sense of security, but the Ministry of Health the other way around. Being transparent, will create panics. And that's not our view.

Anies's statement about the paradigm differences about "transparency" between Anies and the Minister of Health shows that there is something that is being hidden both from the DKI Jakarta government and by the Minister of Health. Anies opinion about being transparent at the beginning of the COVID19 case was detected as an act to 
provide a sense of security proved to be inappropriate. This is evident by the scarcity of finding a variety of Personal Protective Equipment such as masks at pharmacies and minimarkets.

The high price of a firing thermometer is also evidence that at that time, people were panicked by the findings of COVID19 cases. Residents flocked to hoard masks and shot thermometers for themselves. Surgical masks and N95 masks that are needed by medical staff are also rare in the market. Panic also occurs when residents flock to hoard groceries for their supplies at home.

Anies: So that's why we asked for authority to do restrictions, and then when the authority is not there, we have started anyway.

And we did that without asking for authority to do all those restrictions.

\section{James: We had to}

Anies: We had to do that.

The contradiction between Anies and the Minister of Health was increasingly apparent when Anies made a unilateral territorial restriction regulation. The COVID19 case, which has been determined as a national disaster, makes everything that is done by the local Government must be coordinated with the national Government.

However, it seems that Anies was brave enough to conduct territorial restrictions without coordination with the national Government. This became even more "justified" when James replied Anies's statement with the statement "we had to". James's statement, which is a propagation strategy, was welcomed by Anies, who affirmed the statement "we had to do that". Anies's counter-statement can be interpreted that what Anies is doing is the right thing and can be continued even though it has the potential to cause conflict with the National Government.

James: It's interesting. Every time, I tweeted something about you, I get thousands and thousands of shares and likes, actually praising in social media.

I think a lot of Jakartans are very very happy with your performance and not so happy with bapak Jokowi. It's true.

There is an interesting statement made by James. He made a comparison between Anies and President Jokowi. Another attempt made by James to win Anies' heart. President Jokowi's performance, which is said to be no less good than Anies, emphasizes that James is confident in everything that Anies made. James is implicitly convinced that Anies has done something right. 
Anies: In the month of April, it is also around 4590 funerals in that month. And that is four weeks.In the month of March, most of those service is in the third or fourth week. And the number is around 4300. So, if we assume, that case fatality rate is between $5-10 \%$, then the real cases out there is between 8000, 9000, sorry 40.000 to 80.000 perhaps.

Something is interesting here, namely the use of the words "assume" and "perhaps". Choosing these two words may mean Governor Anies is in a condition that is uncertain of what has been said. Those words make the statement of Anies is open for alternative positions in the dialogue. The word 'perhaps' suggests the lack of attention to the true meaning of the proposals. Anies's strategy is categorized in tactics of showing perspectives. Anies predicted the actual number of positive COVID19 cases.

Anies: Pak James, this is the time in which policymakers need to trust science. This is the time to prove that our public policy is based on the scientific findings. And I'm going to continue to rely on science to tell us about this issue.

James: That's an excellent policy Governor. I wish there are more Government around the world that will doing that some are but not all of them.

Anies reiterated his argument by making a plan. When viewed from Anies's statement, the plan that Anies made did indeed look right by trusting science. As we know that scientific discovery requires in-depth research by the scientific field. However, James's reply to Anies's statement made it seem as if what had been done by the National Government was not based on scientific research.

James showed his hope that he wanted more governments to emulate Anies's steps. By saying "government" instead of "local government" shows that the national Government does not use opinions or scientific results in determining its steps to deal with the COVID-19 outbreak. Praise given by James reinforces Anies's plan.

Anies: Let me give you an illustration. On March 30, we closed down intercity terminals. The Jakarta Government did that. And then it's overruled. Unfortunately.

Last year, just an illustration, 7 million people did mudik.

Let me give you an illustration. When we heard about the cases in Wuhan, late December, early January. On the $6^{\text {th }}$ of January, we already started to have meetings with all hospitals in Jakarta.

To give you an illustration. Total ICU that we have is around 12.000. we have 12000 ICU, however only around 900 were filled with patients.

In Anies's interview with James Masolla, Anies gave 4 (four) illustrations. Anies shows the steps Anies has taken in dealing with the COVID-19 outbreak. But 
unfortunately, Anies again showed that there were problems that occurred between the DKI Jakarta government and the national Government. This is indicated by the use of the words "overruled" and "unfortunately".

Anies's decision to close the inter-city bus terminal was met with the cancellation of the decision. The only Government that can overturn this decision is the national Government. The cancellation implies that there is no good coordination between the DKI Jakarta government and the national Government.

James: You've won a lot of praise for your handling of this crisis; I wouldn't argue you are in the front row for the 2024 presidential election. Is that something what you think about in the back of your mind?

Anies: No, no. This is too early to talk about anything which is still going on for the next 4 years. ....... Hopefully it's over soon and then we can discuss more general including an election.

Propagation strategy was again used by James to get Anies to do or admit something. Although Anies initially refused to discuss everything related to the 2024 presidential election, in the end, Anies also agreed to James's "invitation" to discuss the presidential election after the COVID-19 outbreak was over. This shows that implicitly, Anies does have a purpose that leads to the presidential election in 2024.

\section{CONCLUSIONS}

An interview by the Governor of DKI Jakarta, Anies Rasyid Baswedan, with a contributor from The Sydney Morning Herald named James Masolla, indeed captured the attention of the people of Indonesia. The quality of the argument given by Anies is excellent because it can provide a probability claim and provide a desirably claim. Anies, who is also considered a strong candidate in the 2024 presidential election contestation, used the overall persuasion strategy put forward by Kochneva and Titova.

The study in the political discourse of persuasion theory is a complex and coherent entity that covers many aspects of our lives. The topical issue that occupies the minds of the entire nations is frequently used because political strategies may be reflected. The usage of the persuasive approach has been found to help in interpreting the meaning of an argument. Persuasive techniques may often be used to anticipate the reaction and what the interlocutors intend to do. 


\section{REFERENCES}

Amaglobeli, Givi. (2017). Types of Political Discourses and Their Classification. In Journal of Education in Black Sea Region. Vol. 3. Issue 1. Pp. 18-24.

Bayram, Fatih. (2010). Ideology and Political Discourse: A Critical Discourse Analysis of Erdogan's Political Speech. In ARECLS. Vol. 7. Pp. 23-40.

Blommaert, J. (2019). Political Discourse in Post-Digital Societies.

Coupland, N., Williams, A. and Garret, P. (1994). The Social Meanings of Welsh English: Teachers' Stereotyped Judgments. In Journal of Multilingual and Multicultural Development. Vol. 15. Pp. 471-491.

Edwards, J. (2006). Language Attitudes. In Brown, K. (eds), The Encyclopedia of Language and Lingistics. Vol. 6. Pp. 324-331. New York: Pergamon Press.

Fasold, R.W. and Connor-Linton, J. (2006). An Introduction to Language and Linguistics. New York: Cambridge University Press.

Giles H, and Coupland, N. (1991). Language: Contexts and Consequences. Pacific Grove: Books/Cole Pub.

Holmes, J. (2001). An Introduction to Sociolingistics. Harlow: Longman.

Jones, J. and Peccei, J. S. (2004). Language and Politics. In Thomas, L. (Eds). Language, Society, and Power. New York: Routledge.

Kenzhekanova, K. K. (2015). Linguistic Features of Political Discourse. In Mediterranean Journal of Social Sciences. Vol. 6. Pp. 192-199.

Kochneva, I and Titova, E. (2019). Political Discourse in Cinematic Discourse (Based on 'Shrek-3'). In The European Proceedings of Social \& Behavioural Sciences. Pp. 694-699.

Martin, J.R. and White, P.R.R. (2005). The Language of Evaluation: Appraisal in English. London: Palgrave Macmillan.

Moheddin, R.K. and Sherwani, K.A. (2020). Hedges Used n English Political Discourse. In Twejer. Vol 3. No. 1. Pp. 1112-1077.

Polit, DF \& Beck, CT. (2004). Nursing research: principles and methods. 7th edition. Philadelphia: Lippincott Williams \& Williams.

Qaiwaer, S. N. (2020). A Study of Irony in Political Discourse. In Arab World English Journal: Special Issue on the English Language in Iraqi Context. Pp. 2-17. 
Renkema, J and Schubert, C. (2018). Introduction to Discourse Studies New Edition. Philadelphia: John Benjamin Publishing Company.

Skhvortsova, E. I. (2017). Political Discourse in Linguistics: Peculiar Characteristics. In Molodoj Ucheniy. Vol. 9. Pp. 374-376.

Sudaryanto. (2015). Metode dan Aneka Teknik Analisis Bahasa. Yogyakarta: Sanata Dharma University Press.

Sukhanov, Yu. Yu. (2018). Political Discourse as Object of Linguistic Analysis. In RUDN Journal of Language Studies, Semiotics, and Semantics. Vol. 9. No. 1. Pp. 200-212.

Sutomo, J. (2016). Appraisal System Recognized in President's Jokowi Speech at the APEC SEO Summit 2014 in Beijing, China. In Dinamika Bahasa dan Budaya. Vol. 11. No. 1. Pp. 19-35.

Titova, E. A. (2018). Rechevyie Strategii i taktiki v politicheskom diskurse (na material rechi Hillary Clinton na vruchenii premii 'Chudo-Zhenschine'). [Speech Strategies and Tactics in Political discourse (in the speech of Hillary Clinton during the award ceremony of 'Wonder-Woman')]. in Professionalny proekt: ideyi, tekhnilogii, rezultaty. Vol. 3. No. 32. Pp. 119-137.

Trudgill, Peter. (1992). Introducing Language and Society. London: Penguin Books.

van Dijk, Teun A. 1997. What is Political Discourse Analysis?. In Belgian Journal of Linguistics. Vol. 11. No. 1. Pp. 11-52.

van Dijk, Teun A. (2006). Politics, Ideology, and Discourse. In Brown, K. (eds), The Encyclopedia of Language and Linguistics. Vol. 9. Pp. 728-740. New York: Pergamon Press.

Vidhiasi, Dhion M. (2016). The Analysis of Sumber Waras Case in Sindonews' Editorial "Sumber Waras bukan Pertarungan Opini" Dated April 15 , 2016. In Proceedings of International Seminar Language Maintenance and Shift (6): 5156. Semarang: Diponegoro University.

YouTube Channel "Miecko One Seven". Retrieved from You Tube: https://www.youtube.com/channel/UCtYkvNExkoJc1yrbvfiGHFA 